\title{
STUDY THE ATTITUDE OF THE UKRAINIAN CITIZENS TO THE ENVIRONMENTAL PROBLEMS IN THE CONTEXT OF THE THEORY OF GENERATIONS
}

\author{
A. Volkova, Ia. Proskurova, L. Yevsieieva
}

\begin{abstract}
Мета. Вивчення ставлення до екологічних проблем громадян Украӥни в контексті теорії поколінь $X$, $Y, Z$. Матеріали та методи. За допомогою аналітико-порівняльного, системно-аналітичного, математикостатистичного, логічного методів аналізу та методу анкетування, а також описового та абстрактного моделювання й узагальнення було досліджено екологічний портрет громадяна України.

Результати. В умовах зростання глобальної екологічної кризи, екологічний підхід стає головною тенденцією для стабільного розвитку держави. Економічне і сочіальне благополуччя тісно пов'язане із станом навколишнього середовища, яке може існувати стабільно лише в певних екологічних та ресурсних межах. Тому особливу увагу слід приділити ставленню людей до навколишнього середовища як суспільного блага і формуванню їх екологічно відповідальної поведінки, яка стає все більш важливим елементом у міжнародних програмах захисту нашого спільного довкілля. За результатами досліджень встановлено ставлення до екологічних проблем громадян України різних поколінь та виявлено основні тенденції в домінуванні типів поведінки і характерологічних особливостях представників покоління Z. Встановлено, щзо громадяни України 3-х поколінь (X, Y, Z) поділяють спільні екологічні иінності - вони вважають охорону довкілля важливою та впевнені, щчо можуть особисто відігравати роль у захисті довкілля. Проте, можна говорити, щуо екологічні практики мешканців Украӥни все щче потребують особливої уваги з боку державних органів та громадських організацій.

Висновки. Визначено ставлення до екологічних проблем громадян Украӥни в контексті теорії поколінь та узагальнено їх спільні екологічні цінності. За результатами досліджень визначено основні напрямки у підвищенні рівня екологічної свідомості громадян. Так, запропонована активна робота з молоддю, оскільки для представників покоління $Z$ не є властивим дбайливе відношення до природних ресурсів та екології в цілому. Зокрема, така робота можлива шляхом впровадження різних еко-практик та підвищення рівня проінформованості громадян щодо екологічних питань. У той же час, актуальним є впровадження заохочувальних та мотиваційних механізмів охорони довкілля з урахуванням потреб та цінностей кожного окремого покоління
\end{abstract}

Ключові слова: екологічний портрет, теорія поколінь, опитування, рівень обізнаності, екологічні проблеми, охорона навколишнього середовища

Copyright (C) 2020, A. Volkova, Ia. Proskurova, L. Yevsieieva. This is an open access article under the CC BY license (http://creativecommons.org/licenses/by/4.0).

\section{Introduction}

In the late 1980s, the International Commission on the Environment and Development proposed the concept of sustainable development (Our Common Future, 1989). Sustainable development is a general concept, the essence of which is that current development must take place without prejudice to the development of future generations. This needs to strike a balance between meeting the modern needs of humankind and protecting the interests of future generations [1].

With the global ecological crisis growing, the environmental approach becomes a major trend for the country's sustainable development. Economic and social well-being is closely linked to the state of the environment, which can only be stable within certain environmental and resource boundaries. Therefore, special attention should be paid to the attitude of people to the environment as a public good and the formation of their environmentally responsible behav- iour, which is becoming an increasingly important element in international programs to protect our common environment [2].

Literature review and problem statement, which looked at the social aspects of environmental issues, showed that nowadays, more and more experts are paying attention to the theory of generations. The use of "theory of generations" allows us to distinguish a system of values of guidance for each generation in order to implement further action measures to motivate and increase the level of environmental awareness and responsibility. Value system - an attribute of consciousness and a regulator of personality behaviour, incorporating social values in the mechanism of activity and decision making personality, defines the "vector" of personality development and provides identification of certain population groups that have value-orientation unity in terms of coincidence of positions [3]. 
Sociologist Carl Mannheim, in an essay in 1923, "The problem of generations", emphasized that the speed of social change was crucial to the formation of generations [4]. Strauss-Howe's approach to the model of generations, developed on the basis of American history of development, determines that generation generalizes a new era in which there is a new social, political and economic climate ("theory of generations") [5, 6]. This model of society, which is divided into different categories of people by age (generation), is especially attractive in view of the large-scale processes of modernization and globalization that have changed the world. It is emphasized that the uniqueness of each generation is formed due to the existing conditions of development and socialization at a young age.

The period of development of a society into which a person is born, influences his or her outlook and system of values. Scientists have drawn attention to a "conflict of generations" that is completely unrelated to age-old contradictions. When they reach a certain age, they acquire the age-specific values of that period, but at the same time, children do not become the same as their parents when they reach the age of their parents, and their attitude to life is different.

The formation of environmental awareness is becoming an increasingly important element in environmental programs in the European and global community as a whole [7]. In view of the above, the aim of this work was to study the attitude to contemporary environmental problems of Ukrainian citizens of generations X, $\mathrm{Y}, \mathrm{Z}$, which was conducted through questionnaires. The survey on the attitude of different generations of Ukrainian citizens to the environment is relevant in terms of identifying promising ways of forming environmentally responsible behaviour [8]. The results of this survey provide an opportunity to identify a set of values that contribute to the development of environmental responsibility for different generations.

\section{Planning (methodology) of research}

We conducted a pilot survey with representatives of different age categories. The survey used questions that were included in the EU Survey [8] and adapted according to the poll "Environmental portrait of a citizen of Ukraine", conducted in May 2018 [9].

The survey was conducted from January 1 to January 10, 2019 using an online survey with the Google Forms service. At this stage, we conducted a survey of respondents from Kharkiv and Kharkiv region. In the formation of the sample population a quota selection were used. The quota in this sociological survey was one socio-demographic characteristic - the relation to one of 3 categories of generations. Thus, 43 respondents of generation $\mathrm{X}, 43$ of generation $\mathrm{Y}$ and 43 of generation $\mathrm{Z}$ participated in the survey.

\section{Materials and methods}

In the process of research, analytical-comparative, system-analytical, mathematical-statistical, logical methods of analysis and method of questioning, as well as descriptive method and abstract modulation and generalization were used.
Statistical and mathematical analysis included descriptive statistics: systematization, visual representation in the form of graphs and tables, as well as their quantitative description through the main statistical indicators indicating the total sample size, sample volumes in the studied subgroups, demographic characteristics.

\section{Result of the research}

In order to determine the overall distribution of the population of Ukraine by generations, we analyzed the data of the State Statistics Service of Ukraine. It is estimated that the total population of Ukraine as of early 2018 was over 42 million [10]. The general distribution of the population of Ukraine by generations is shown in Fig. 1.

The distribution data show that the major part of the population of Ukraine is generation $\mathrm{X}$ and $\mathrm{Y}$. It is established that the generation $\mathrm{X}$ in the age from 35 to 54 years made up $28,4 \%$ of the population of Ukraine for the period of analysis, and the generation $\mathrm{Y}$ in the age from 20 to 34 years $-21.3 \%$. At the same time, Generation $\mathrm{Z}$, between the ages of 15 and 19 , was only $4.4 \%$. However, in a few years' time, Generation $Z$ itself will make up more than $20 \%$ of the population and begin to play a key role in the development of society, in addressing pressing issues of politics, economy and ecology. From the point of view of influencing the formation of environmental consciousness can be considered the most promising educational work with the representatives of generation $\mathrm{Z}$.

The study examined the level of citizens' awareness of key environmental issues in the world, clarified their relevance to current environmental and social issues in Ukraine, etc. Particular attention was paid to the analysis of the attitude towards environmental problems of the $\mathrm{Z}$ generation.

Some questions that were asked to respondents of different generations received close answers. Nevertheless, in general, the survey revealed differences in views, such as the impact of environmental issues on life and health, the level of trust in regional / local government, the use of different environmental practices, and more (Fig. 2).

Thus, the most important environmental problems were attributed by respondents of different generations: waste growth $42 \%(\mathrm{X}), 28 \%(\mathrm{Y}), 26 \%(\mathrm{Z})$; pollution of rivers, lakes or groundwater $-26 \%(\mathrm{X}), 30 \%(\mathrm{Y}), 12 \%$ (Z); air pollution $-26 \%(\mathrm{Y}), 21 \%(\mathrm{Z})$. If category $\mathrm{X}$ has identified almost unanimously 2 major problems, $\mathrm{Y}$ is 3 problems, then $\mathrm{Z}$ categories have differences.

It was found that the main sources of environmental information for citizens of generation X (53\%) and Y $(74 \%)$ are social networks, the Internet and news on television. As Generation X grew early in the introduction of new technologies, this generation is characterized by a high level of scepticism. Generation Y grew up with computers, multi-channel satellite and cable TV, mobile phones, etc.

The emergence of the Internet and social networks is part of their own information support system as well as a news source. They are used to answering any questions right away using the Internet (Fig. 3). 


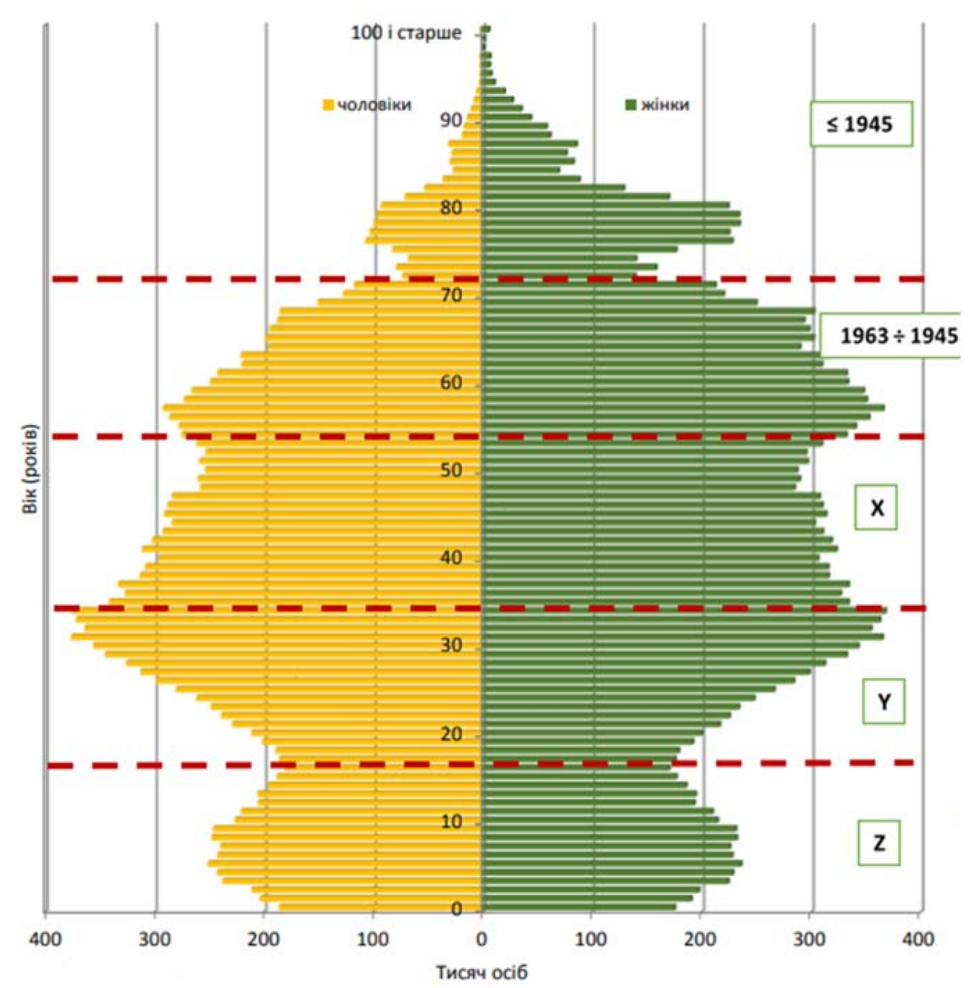

Fig. 1. Total population distribution (by age and sex) in Ukraine

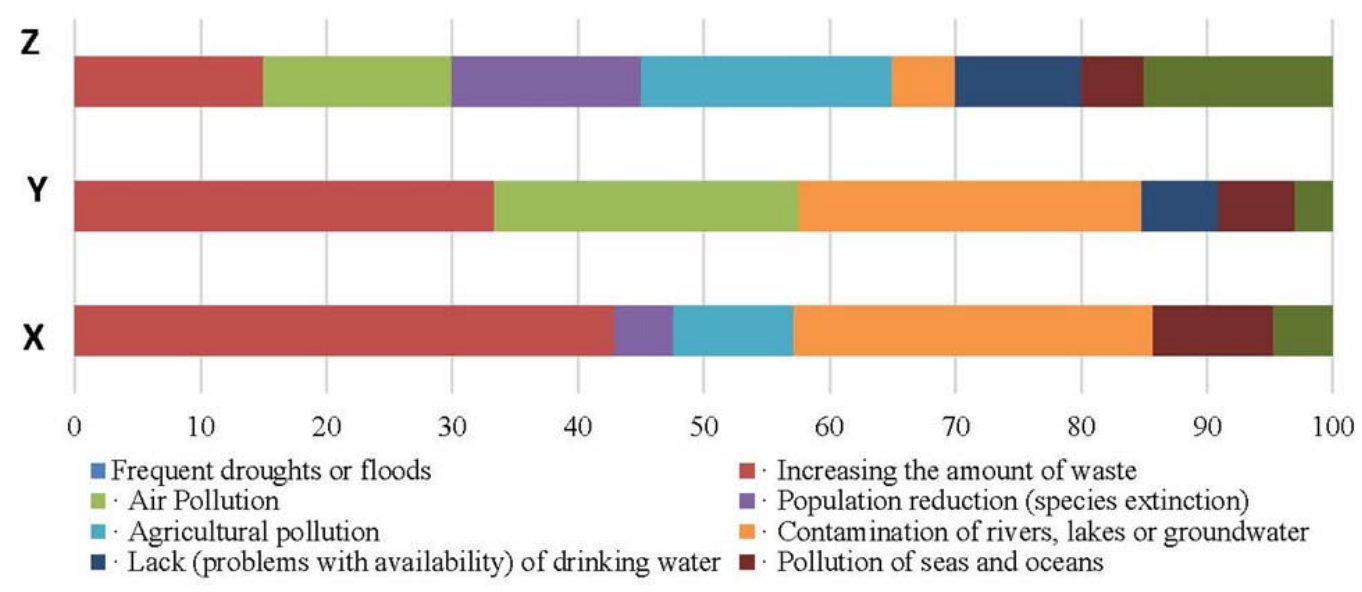

Fig. 2. Distribution of answers to the question: "What do you think are the most important environmental problems of today?"

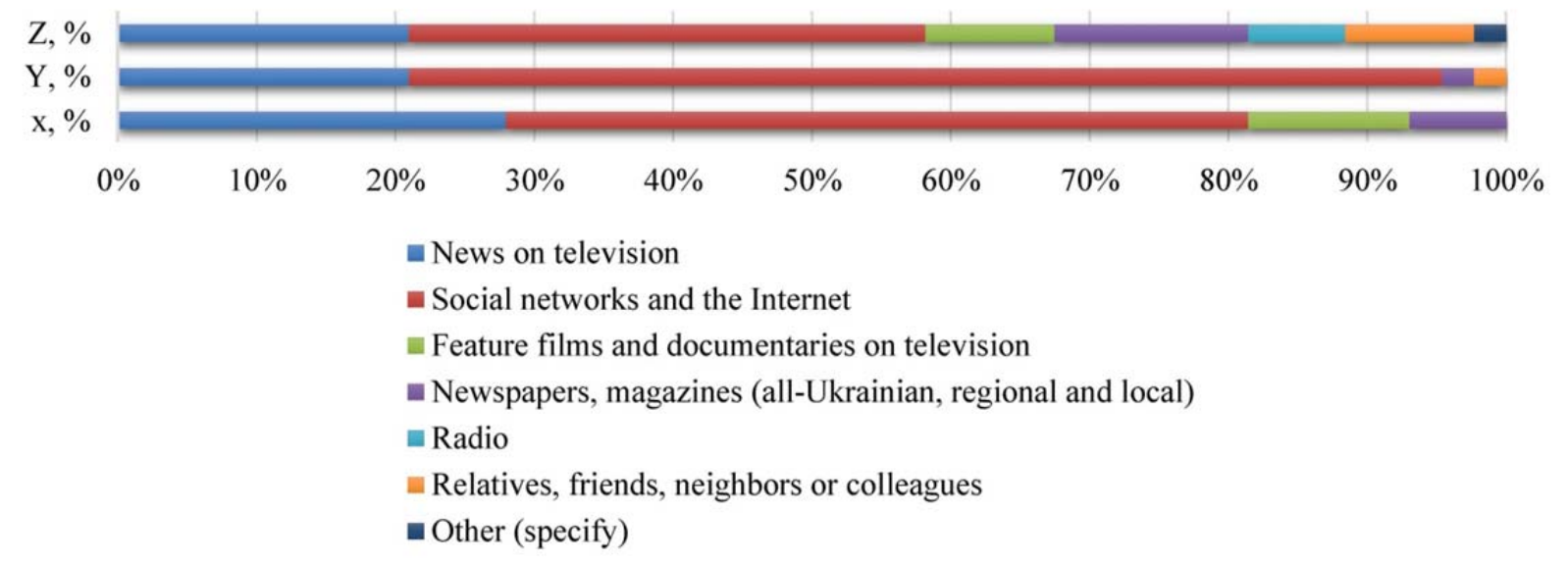

Fig. 3. Distribution of answers to the question: "What are the main sources of environmental information for you?" 
The results of our study on Generation Z's view of information sources correlate with the findings of Ipsos MORI [11]: generation $\mathrm{Z}$ is the first early childhood Internet support group, but it is much more legible in online sources. Its main difference is a decrease in online news credibility. They are less likely to trust information simply because it is on the Internet. The $\mathrm{Z}$ generation is watching less television and more on-demand information through video-on-demand and YouTube services. Therefore, video content is an important source of information for Generation $\mathrm{Z}$.

According to the results of the survey, it was found that in the question of confidence in the activities of the relevant organizations in identifying and solving environmental problems, the opinions of the respondents were distributed as follows: generation $\mathrm{X}$ has a high level of distrust in state and international bodies; generation Y is more trusting of international organizations; generation $\mathrm{Z}$ - trusted by government bodies (local and central government). It should be noted that generation $\mathrm{Z}$ representatives are more likely to trust other people and, according to Ipsos MORI [11], are introducing a model of increasing trust in the central government and civil servants. The largest percentage of respondents trust scientists (generation $\mathrm{X}-21 \%$ and $\mathrm{Y}-26 \%$ ) and proenvironmental political parties (generation $Z-19 \%$ ) in environmental matters.

Environmental protection is important for $81 \%$ of generation $\mathrm{X}$ respondents and $93 \%$ of generation $\mathrm{Y}$, because they consider it an important issue for themselves (Fig. 4). This fact is explained by the fact that these generations have witnessed man-made disasters and understand that humanity can and should control the environment. However, $53 \%$ of generation $\mathrm{Z}$ members do not yet fully understand this problem or have insufficient information. $63 \%(\mathrm{X}), 49 \%(\mathrm{Y}), 33 \%(\mathrm{Z})$ of the respective surveyed generations believe that respondents can personally play a role in protecting the environment.

Generation representatives also responded differently to the question "What have you been doing to protect the environment in the last 6 months?" (Fig. 5). The survey found that generation $\mathrm{X}$ and $\mathrm{Y}$ are more likely to exhibit environmental behaviour in the presence of a financial component: for example, a way of influencing the environment by saving on the costs of using natural resources. Therefore, the answers to this question were:

- reduction of energy and water consumption:

- garbage sorting: $\mathrm{X}-30 \%, \mathrm{Y}-12 \%, \mathrm{Z}-11.3 \%$;

- reduction of the use of plastic packaging (disposable packages):

$$
\mathrm{X}-18 \%, \mathrm{Y}-14 \%, \mathrm{Z}-25.6 \% \text {; }
$$

- use of ecological transport (bicycle, electric car, etc.):

$$
\mathrm{X}-12 \%, \mathrm{Y}-33 \%, \mathrm{Z}-30.2 \% \text {. }
$$

The answers to the following questionnaire on the impact of eco-labelling on the choice of goods revealed the need to disseminate information on the feasibility of eco-labelling of goods as one of the approaches to environmental protection (Fig. 6).

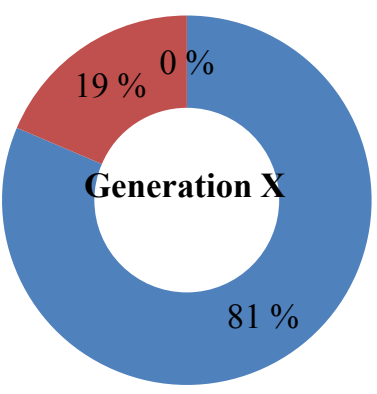

- Very important + Rather important

Not very important + not important

Difficult to answer

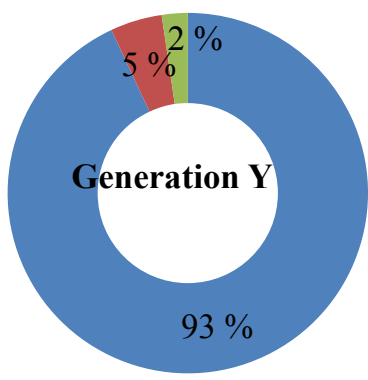

Very important + Rather important

Not very important + not important

Difficult to answer

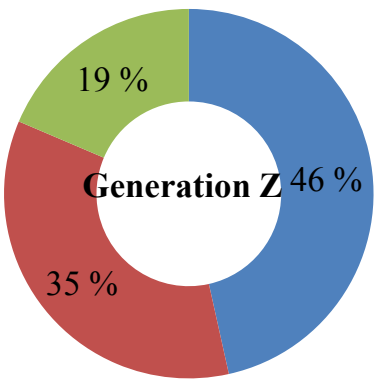

- Very important + Rather important

Not very important + not important

Difficult to answer

Fig. 4. The results of the analysis of the answers to the question: "How important for you personally is the environment?": $a$ - generation $\mathrm{X}$; $b$ - generation $\mathrm{Y} ; c$ - generation $\mathrm{Z}$ 


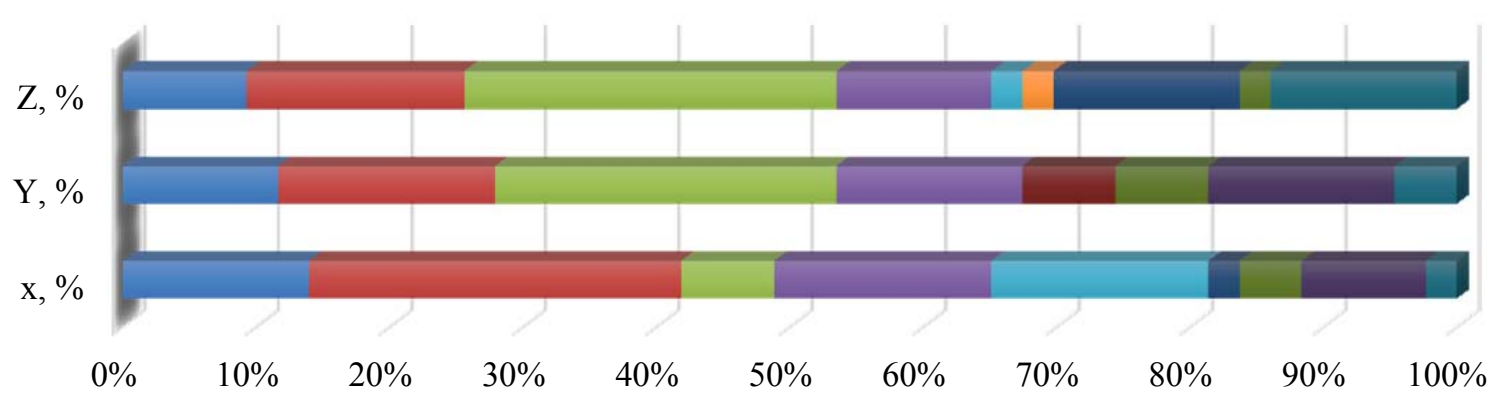

Reduced energy consumption

- Sorted most of the trash for recycling

Has opted for cleaner transport (on foot, bike, etc.)

- Avoid buying disposable plastic products except packages

- Reduced household water consumption

I I bought goods from local manufacturers

- Avoid buying excessively packed goods

- I bought eco-labeled products

- Less used your car

- Difficult to answer

Fig. 5. Distribution of answers to the question: "What have you been doing to protect the environment in the last 6 months?"

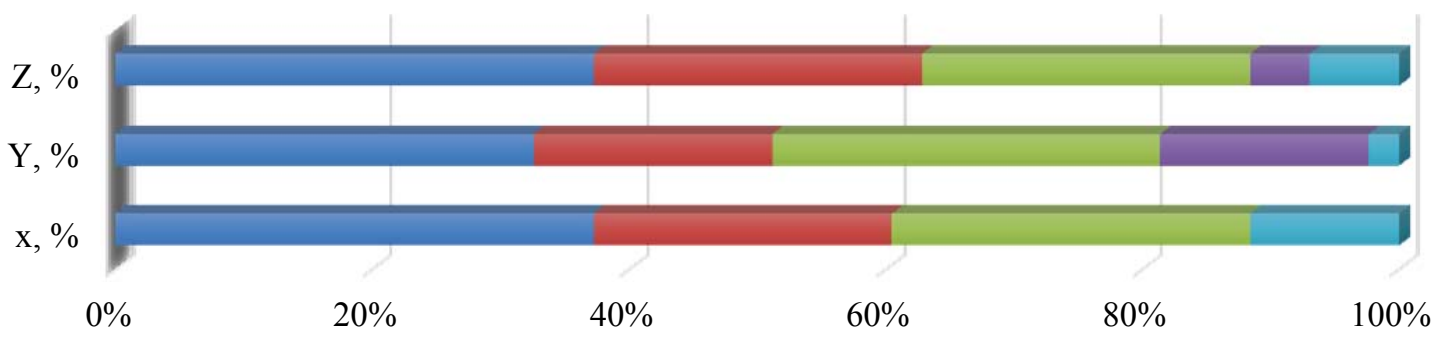

Eco-labeling is important for my decision to buy or not

Eco-labeling is not important for my decision to buy or not

I do not pay attention to marking at all

- Other

Fig. 6. Distribution of answers to the question: "What is the impact of eco-labelling on your choice of goods?"

It was found that for $23 \%$ of generation $\mathrm{X}$ respondents, $19 \%$ of generation Y citizens, and $21 \%$ of generation $\mathrm{Z}$ eco-labels are not important for the decision to purchase a product. In addition, $28 \%, 31 \%, 26 \%$ of the polled representatives of each generation do not pay attention to this type of marking at all.

The content of the questionnaire envisaged a number of questions on measures to improve the environmental literacy of citizens and address environmental issues.

Thus, the most effective approaches to solving environmental problems, representatives of generations $\mathrm{X}, \mathrm{Y}, \mathrm{Z}$ include the following:

a) introduction of higher fines for environmental pollution (X - $23 \%, \mathrm{Y}-14 \%, \mathrm{Z}-19 \%)$;

b) adopting more stringent environmental laws (X-14\%, Y - $14 \%, Z-9 \%)$;

c) increase of accessible and quality information for the population on environmental issues $(\mathrm{X}-12 \%$, $\mathrm{Y}-5 \%, \mathrm{Z}-23 \%)$; d) ensuring better implementation of applicable environmental legislation ( $\mathrm{X}-9 \%, \mathrm{Y}-5 \%, \mathrm{Z}-21 \%$ );

e) introduction of training programs to help people understand current environmental issues and change their habits towards green technologies (X - $16 \%$, $\mathrm{Y}-28 \%, \mathrm{Z}-16 \%$ );

f) implementation or enhancement of financial incentives for business and people to use "environmental solutions" (X - 19\%, Y - 21\%, Z - 5\%).

It should be noted that generation $Z$ found it difficult to answer some of the questions. In our opinion, this is due to an unformed viewpoint and a lack of information on these issues. Therefore, most of the answers are difficult to answer:

- Are large enterprises doing enough to protect the environment?

- Is there enough government (central government), city authority to do for the environment?

- Is the EU doing enough to protect the environment? 
Generations $\mathrm{X}$ and $\mathrm{Y}$, however, answered these questions that the government's actions were insufficient to protect the environment.

Respondents identified various topical issues that need to be prioritized when it comes to environmental reform issues (Fig. 7). The differences can be explained by the differences in the content of information that was conveyed through the media during different periods of life of each generation:
- environmental management and integration of environmental policy into other sectoral policies: $(\mathrm{X}-44 \%, \mathrm{Y}-33 \%, \mathrm{Z}-14 \%)$;

- atmospheric air quality $(\mathrm{X}-14 \%, \mathrm{Y}-5 \%$, $\mathrm{Z}-18,6 \%$ );

- waste and resource management ( $\mathrm{X}-28 \%$, $\mathrm{Y}-33 \%, \mathrm{Z}-14 \%$ );

- water quality and water management, including the marine environment: $(\mathrm{X}-9 \%, \mathrm{Y}-5 \%, \mathrm{Z}-28 \%)$.

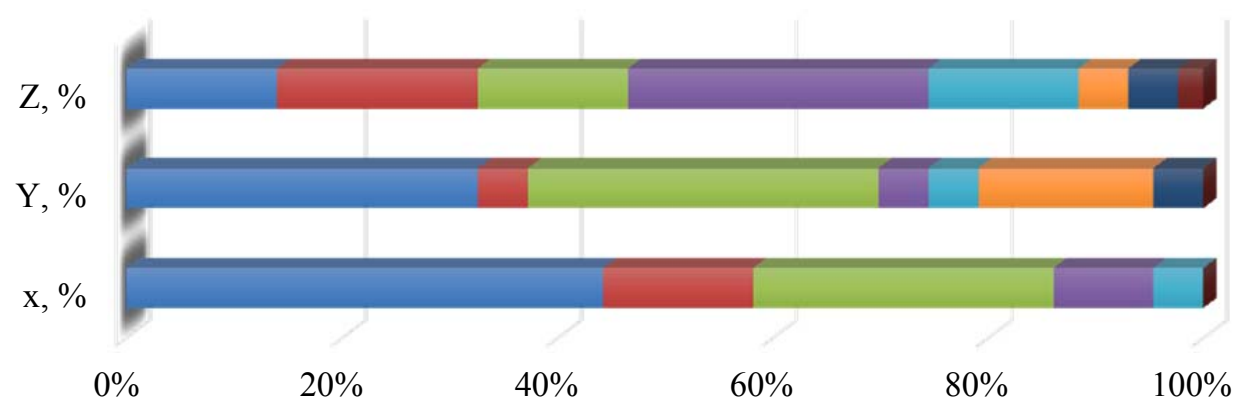

Environmental management and integration of environmental policy into other sectoral policies

The quality of the atmospheric air

Waste and resource management

Water quality and water management, including the marine environment

- Conservation

Fig. 7. Distribution of answers to the question: "Priority reforms in the field of environmental protection in your opinion?"

\section{Discussion of the research results}

According to the research, opinion on environmental problems and vision of ways to solve them differ among citizens, depending on their age. The conditions in which each generation is born, nurtured, grown and developed have a significant impact on citizens' perceptions of environmental information.

In 2017, the European Commission released the results of an environmental survey conducted in 28 countries of the European Union. The survey was conducted by TNS Political \& Social from September 23 to October 2, 2017 among different social and age groups [8]. Within the framework of the project "Ecologically conscious citizen - the key to successful implementation of the Association Agreement", with the assistance of the EU, a poll was conducted on the opinion of Ukrainian citizens on their attitude to the environment, as well as a comparison of the results with a similar poll in the EU. The main conclusion of this survey is that Ukrainians and EU citizens share basic environmental values [10].

The findings of our study correlate with the findings of Ipsos MORI [11], which published the 2018 "BEYOND BINARY. The lives and choices of Generation Z" regarding the values of generation $Z$.

Thus, according to the results of this stage of the research, the attitude towards environmental problems of the interviewed representatives of different generations was determined, and the main tendencies in the dominance of the types of behaviour and character traits of the representatives of the generation $\mathrm{Z}$ were revealed. According to the survey, it can be stated that citizens of Ukraine of 3 generations (X, Y, Z) share common environmental values and consider environmental protection important and confident that they can personally play a role in environmental protection. However, it can be said that the environmental practices of Ukrainian residents still need special attention from state bodies and public organizations. Therefore, additional steps are needed to raise environmental awareness and support environmental reforms that will bring about qualitative change in the future.

Environmental protection is important for $81 \%$ of generation X citizens, $93 \%$ of generation Y citizens, and $47 \%$ of generation $Z$ citizens. They believe that $63 \%$, $49 \%, 33 \%$ of the respective surveyed generations can play a personal role in protecting the environment. Such low indicators of the importance of environmental protection and self-reliance on the citizens of generation $\mathrm{Z}$ indicate that, today, the environmental education of young people needs to be revitalized and changed. In our opinion, ecological education with a view to shaping environmental awareness should play a particularly important role in this situation. The thorough preparation of citizens with a high level of environmental knowledge, 
environmental awareness and culture based on new criteria for assessing the relationship between human society and nature should become one of the major levers in solving the extremely acute environmental and socioeconomic problems of modern Ukraine. Citizens should receive more information about environmental issues and their causes. The questionnaire is found to be difficult for the respondents to consider the impact of environmental factors on the lives and health of Ukrainians, which is explained by the lack of objective information needed. Open public credible environmental information should be disseminated through social networks, the Internet and television. They are the main sources of environmental information for citizens of generations X (53\%) and Y (74\%).

We believe that specific scientific mechanisms should be put in place to assess the impact of environmental factors on the lives and health of Ukrainians, as it is found that the highest percentage of respondents trust scientists (generation $\mathrm{X}-21 \%$ and $\mathrm{Y}-26 \%$ ) and political parties, occupying a pro-ecological position (generation $Z-19 \%)$. Therefore, when preparing analytical documents, reports and justifications for environmental reforms, it is necessary to involve scientists, use the results of their research and the development of specialized political parties.

We have also identified the need to disseminate information on the feasibility of using eco-packaging as one of the environmental approaches. For $23 \%$ of generation $\mathrm{X}$ citizens, $19 \%$ of generation $\mathrm{Y}$ citizens, and $21 \%$ of generation $\mathrm{Z}$ eco-packs are not important to decide whether to buy or not, and $28 \%, 31 \%, 26 \%$ of each generation's generic people do not pay attention to this packaging at all. Environmental initiatives or advertising campaigns need to be put in place, since environmental labelling of goods depends on preserving the health of future generations, developing the country and its economy. More emphasis should be placed on promoting proenvironmental practices, the benefits of using them, and educating citizens of different generations.

When selecting priorities in reforming environmental approaches, the low level of public awareness of the activities of the authorities on these issues should be taken into account.

Of course, special attention is needed to work with young people - with representatives of the $\mathrm{Z}$ generation, because behind them is our future. Despite the ste- reotypes of youth information progressiveness on many issues, the generation $\mathrm{Z}$ respondents are not the first to take care of natural resources and the environment as a whole. In particular, this concerns the implementation of various eco-practices and the ability to pay a personal contribution in environmental protection.

Therefore, in formulating strategies and projects on environmental education, the authorities and civil organizations should be made aware that citizens are unconditionally carriers of basic ecological values and are in the same ecological value space with the EU. Environmental promotion and motivation mechanisms should also be understood and implemented, taking into account the needs and values of each generation.

Study limitations. The limitations of our study include a limited sample size. The results of the survey are based on the personal opinion of the respondents, which is not subject to factual verification. However, this research provides an insight into the problem and provides the basis for a more complete study in the future.

Prospects for further research. Taking into account the obtained results at this stage of the study, we consider the prospect of expanding the sample of respondents and regions of Ukraine in further studies. Determining the attitude of different generations to environmental problems will more effectively outline ways that contribute to the formation of environmentally conscious behaviour, as well as engage citizens of all generations to actively participate in environmental initiatives and support modern approaches to environmental protection that will deliver quality change in the future in the context of sustainable development.

\section{Conclusions}

The attitude to the environmental problems of Ukrainian citizens in the context of the theory of generations was determined and their common ecological values were generalized. The results of this survey give an opportunity to understand the attitude to environmental problems of different generations and to identify their set of values that contribute to the formation of environmental consciousness. According to the research, the main directions in raising the level of environmental awareness of citizens are identified.

\section{Conflict of interests}

The authors declare no conflict of interest.

\section{References}

1. Povestka dnia na XXI vek. Konventsyia OON. Available at: http://www.un.org/ru/documents/decl_conv/conventions/ agenda21.shtml

2. Proskurova, Ia. O., Kubarieva, I. V., Karpenko, K. I., Yevsieieva, L. V. (2019). Vyznachennia ekolohichnykh portretiv riznykh pokolin hromadian Ukrainy. Sotsialna farmatsiia: stan, problemy ta perspektyvy. Kharkiv, 139-141.

3. Yanickii, M. S. (2000). Cennostnye orientacii lichnosti kak dinamicheskaya sistema. Kemerovo: Kuzbassvuzizdat, 204.

4. Pilcher, J. (1994). Mannheim's Sociology of Generations: An under valued legacy". The British Journal of Sociology, 45 (3), 481-495. doi: http://doi.org/10.2307/591659

5. Howe, N. (1992). Generations: The History of America's Future, 1584 to 2069. Available at: https://archive.org/details/ GenerationsTheHistoryOfAmericasFuture1584To2069ByWilliamStraussNeilHowe/page/n3

6. Teoryia pokolenyi X Y Z. Available at: https://4brain.ru/blog/теория-поколений-хуz/

7. Proskurova, Ia. O., Kubarieva, I. V., Yevsieieva, L. V., Prosianyk, L. F.(2018). Otsinka obiznanosti fakhivtsiv haluzi okhorony zdorovia shchodo problem utylizatsii neprydatnykh likarskykh zasobiv naselenniam. Upravlinnia yakistiu $\mathrm{v}$ farmatsii. Kharkiv, 155. 
8. Special Eurobarometer 468 - "Attitudes of European citizens towards the environment" Summary. (2017). European Commission. Available at: http://ec.europa.eu/commfrontoffice/publicopinionmobile/index.cfm/Survey/getSurveyDetail/surveyKy/2156

9. Ekolohichnyi portret hromadianyna Ukrainy: porivniannia z YeS ta rekomendatsii. Analitychnyi dokument. Resursnoanalitychnyi tsentr "Suspilstvo i dovkillia" (2018). Available at: https://www.rac.org.ua/priorities/political-processes-and-theenvironment/citizens-attitudes-towards-the-environment/citizens-environmental-portrait-2018

10. Naselennia Ukrainy za 2017 rik. Demohrafichnyi shchorichnyk. Kyiv: Derzhavna sluzhba statystyky Ukrainy, 138. Available at: http://database.ukrcensus.gov.ua/PXWEB2007/ukr/publ_new1/2018/zb_dy_2017.pdf

11. Beyond binary. The lives and choices of Generation Z (2018). Available at: https://www.ipsos.com/sites/default/files/ 2018-08/ipsos_-_beyond_binary_-_the_lives_and_choices_of_gen_z.pdf

Received date 23.03.2020

Accepted date 16.04.2020

Published date 30.04.2020

Alina Volkova, PhD, Associate Professor, Department of Social Pharmacy, National University of Pharmacy, Pushkinska str., 53, Kharkiv, Ukraine, 61002

E-mail: socpharm@nuph.edu.ua

Iana Proskurova, PhD, Assistant, Department of Social Pharmacy, National University of Pharmacy, Pushkinska str., 53, Kharkiv, Ukraine, 61002

E-mail: socpharm@nuph.edu.ua

Larysa Yevsieieva, Chairman of Organization, Social Organization "Social and Environmental Safety", Assistant Department of Organic Chemistry, V. N. Karazin Kharkiv National University, Svobody sq., 4, Kharkiv, Ukraina, 61022

E-mail: lar0858@gmail.com 